methods of study adopted to demonstrate the physical laws that controlled plant activity.

Following these fine contributions to biochemical and biophysical science, both Brown and Escombe took up appointments in the Scientific Research Laboratory of Messrs. Guinness and Co. at Dublin, Brown as director and Escombe as vegetable physiologist. The work on improving the malting qualities of barley was published (unsigned) in the Laboratory Transactions. Escombe worked there from July 1901 for three years. Readers of NATURE will remember the excellent reviews by Escombe on German biochemical works by Emmerling, Schulz, Czapek and Wieler about this time (1902-6). He wrote for Science Progress, 1897-98, two papers on germination generalised from the Royal Society researches.

Escombe then held the post of lecturer in botany and head of the Botanical Department at the SouthEastern Agricultural College, Wye, following Mr. (now Sir) Albert Howard, and at the same time gave County Council lectures in Kent and Surrey. $\mathrm{He}$ was at Wye from July 1905 until July 1907. This ended his active career at the age of thirty-five. $\mathrm{He}$ returned to Kow to do some physiological work at the Jodrell Laboratory in March and April 1910. After that, save for work during the Great War at the Admiralty (1917-22), he retired, from ill-health and other circumstances, to his native county, Hamp. shire (where also lived his great friend, Dr. D. H. Scott), living with his family, and latterly, since 1929, in rooms at East Meon, where he made his home until his death.

There Escombe took an active part in the life of the village, and his chief hobbies were reading and walking, and exploring the flora and fauna of the district. He studied the two Arums, and carried out an exhaustive series of researches on their life-history and ecology, later studying that difficult group of trees, the elms. In both cases he wrote valuable notes upon the species, which, with excellent material, he sent to Kew. He also there wrote a treatise on

'Buds in Winter'. All these should be published posthumously, since they are characterised by the same masterly grasp of details, and the clear and well-conceived enunciation of principles, or of classification, with brilliant and sound analogy, which marked the Royal Society papers published in conjunction with Brown.

Fergusson Escombe was a very reserved man, and of a refined nature. Properly understood, he was a charming companion. He had a most gentle nature, and a great love of animals and for children and old people. His scientific work was characterised by thoroughness and avoidance of hurry, and his experiments were conducted with carefulness and exactitude. It seems a tragedy that a man gifted by Nature with exceptional scientific ability, enlarged by special training, and with so sound a knowledge of biochemistry and physiology, should have had to disappear, through ill-health, from the arena of science at so early an age. Ill-health caused his career to be prematurely shortened, and heart failure has now snatched him from the world, his relations and friends all too soon.

\section{Senator Paolo Orsi}

WE regret to record the death of Senator Paolo Orsi, the distinguished Italian archæologist, which took place at Rovereto on November 8 at the age of seventy-six years.

Paolo Orsi was born in 1859 at Rovereto, which was then Austrian territory, but on completing his studies he settled in Italy. In 1888 he became an inspector of the Museum of Syracuse, and soon afterwards was appointed its director. He applied himself to the exploration of the antiquities of the island of Sicily, and by his discoveries revealed the sequence of Siculan culture from early chalcolithic times down to the period of Greek colonisation, a sequence in which he showed that four separate types of civilisation were to be distinguished. His excavations, more particularly in the neolithic villages of Stentinello, the burial grounds of Megara near Syracuse, and at Gela, made his museum one of the richest, and in some respects of the first importance, for the study of certain aspects and periods of Mediterranean archæology.

In 1907, Orsi was appointed superintendente of Calabria and Basilicata. Here he continued his investigations and discovered the pre-Hellenic sites of Torre Galli, near Monteleone, and of Canale, near Locri, both of crucial importance for the study of the prehistory of the Calabrian peninsula. He undertook a number of excavations under the auspices and mainly at the expense of the Societa Magna Græcia, of which he was president at the time of his death. Among his discoveries was that of an Ionic temple at Locri, the only known example in Magna Græcia. The material from these excavations will be exhibited in a museum now in course of construction at ReggioCalabria. He was also an authority on Byzantine antiquities, which he had studied in both Sicily and Calabria.

At the close of the Great War, Orsi took up his residence in retirement at Rovereto. $\mathrm{He}$ was a member of the Accademia dei Lincei, and was made a Senator in 1924. He was an honorary member of the Society for the Promotion of Hellenic Studies and an honorary fellow of the Royal Anthropological Institute.

\section{WE regret to announce the following deaths :}

Prof. James H. Breasted, professor of Egyptology and oriental history in the University of Chicago from 1905 until 1933, and director of the Oriental Institute, Chicago, on December 2, aged seventy years.

Prof. J. D. Cormack, C.M.G., C.B.E., regius professor of civil and mechanical engineering in the University of Glasgow, on November 30, aged sixtyfive years.

Prof. David C. Gillespie, professor of mathematics in Cornell University, for several years editor of the American Mathematical Monthly, on October 13, aged fifty-seven years.

Prof. J. E. A. Steggall, emeritus professor of mathematics at University College, Dundee, in the University of St. Andrews, on November 26, aged eighty years. 